Brit. J. industr. Med., 1963, 20, 50.

\title{
TETRACHLOROETHANE-A SURVEY
}

\author{
BY \\ R. LOBO-MENDONÇA* \\ From the Department of Medical Inspector of Factories, Government of Maharashtra $\dagger$, Bombay
}

(RECEIVED FOR PUBLICATION MARCH 6, 1962)

The use of tetrachloroethane as a solvent for cellulose acetate in the manufacture of bangles in small factories in India is described. The conditions under which exposure occurs are depicted. In a survey of 380 workers no cases of serious poisoning with jaundice were encountered, but there was a high incidence of nervous complaints, and the predominant symptom was tremor.

The control and prevention of excessive exposure are discussed.

The purpose of this paper is to describe the incidence of poisoning by tetrachloroethane in factories engaged in the manufacture of bangles. About 70 factories of various sizes in the State of Maharashtra employ over 1,500 workers of whom about 450 come in direct contact with tetrachloroethane. There are about 30 more factories in other parts of India.

The plastic bangle industry started in Bombay about 18 years ago and has further developed during the past five years, since imports of similar bangles from the Far East were banned. The bangles are exported from India to the Middle East, Africa, the United States of America, and the United Kingdom. One variety is made from waste cinema film which, until 1954, was made with cellulose nitrate. The solvent then used was a mixture of acetone, butyl acetate, and methylated spirit. When cellulose acetate safety film which was not soluble to this solvent was introduced, one of the manufacturers found that tetrachloroethane could be used.

It was noted that the film layers (deprived of their silver coating) did not adhere to one another unless one of the two surfaces was ground. At present a mixture of acetone and tetrachloroethane in equal proportions is used and during the monsoon some diacetone alcohol is added to prevent haziness. It is estimated that about $2,000 \mathrm{lb}$. of tetrachloroethane are used every month.

A survey was undertaken in $1959-60$ to ascertain what effect tetrachloroethane had on the workers, with the object of designing preventive measures

* Retired from Service, March 1960. Present address: Brito Mansion, Mahim, Bombay 16.

†Formerly known as Government of Bombay. best suited to the size and financial status of industry. Most of the factories were small units housed in temporary structures, and it may be termed a cottage industry.

In Bombay 23 such factories were studied, in which tetrachloroethane was used as the solvent, and 380 workers were examined, representing $80 \%$ of the population employed.

The first and most frequent symptoms were nervous; fine tremors were considered the earliest manifestation upon which reliance could be placed and were observed in 133 of the group examined. The tremors were directly related to the concentration of tetrachloroethane in the air. Gastric symptoms, loss of appetite, nausea, vomiting, pain in the abdomen, and "gas" were also recorded.

\section{Properties and Toxicity}

Tetrachloroethane, $\mathrm{CHCl}_{2} \cdot \mathrm{CHCl}_{2}$, symmetrical acetylene tetrachloride, is a yellowish noninflammable liquid, sp. gr. $1 \cdot 600$, b.p. $147^{\circ} \mathrm{C}$., with a smell resembling chloroform. It is considered to be the most poisonous of the chlorinated hydrocarbons, but is not very volatile (Table 1). Its chronic toxicity can be gauged from the maximum

TABLE 1

ACUTE TOXICITY AND VOLATILITY OF COMMON SOLVENTS (Lehmann, 1911)

\begin{tabular}{l|c|c}
\hline \multicolumn{1}{c|}{ Solvent } & Toxicity & Volatility \\
\hline Carbon tetrachloride & $1 \cdot 0$ & $4 \cdot 1$ \\
Trichloroethylene & $1 \cdot 7$ & $2 \cdot 2$ \\
Chloroform & $2 \cdot 2$ & $6 \cdot 3$ \\
Tetrachloroethane & $9 \cdot 1$ & $0 \cdot 2$ \\
\hline
\end{tabular}


allowable concentration (MAC) when compared with those of similar chlorinated hydrocarbons, e.g. carbon tetrachloride MAC 25 p.p.m.; trichlorethylene MAC 200 p.p.m.; chloroform MAC 50 p.p.m.; and tetrachloroethane MAC 5 p.p.m.

Elkins (1950) considers that its acute and chronic toxicities are of the same order.

Tetrachloroethane is a good, non-inflammable solvent for fats, gum, resins, rubber, oils, etc. and for cellulose acetate there is no better solvent. Its vapour is six times as heavy as air so that appreciable amounts are present at floor level, and its density has to be taken into account in designing exhaust ventilation. It is used for extracting fats and oils, in the manufacture of gas masks, safety goggles, and other rubber articles, the manufacture of films, adhesives, and floor waxes, and in impregnating furs and skins. In France, the nacreous lustre with which artificial pearls are treated was prepared by dissolving fish scales in this solvent, and at present this industry is quite common in Japan. During the First World War aeroplane wings were rendered waterproof by spraying them with a solution of cellulose acetate in tetrachloroethane, but as many cases of poisoning developed its use was discontinued in the industry. Its use as a dope and as a lustre in the manufacture of artificial pearls has been prohibited in England (Chief Inspector of Factories, 1959) and most countries. Another field for its use is the artificial silk industry.

\section{Previous Clinical Studies}

There have been a number of reports (Barlow, 1916; Chief Inspector of Factories, 1959; Elliott, 1933; Forbes, 1943; Hamilton, 1917; Hepple, 1927; Lee, 1916; Smith, 1918a and b; Willcox, 1914, 1915, 1916) of the toxicity of tetrachloroethane since Jungfer (1914) made his first report of cases of poisoning due to tetrachloroethane in a German aeroplane factory. Here four out of eight workers developed acute yellow atrophy of the liver after exposure to aeroplane "dopes". Parmenter (1921, 1923) was so successful in his preventive approach that not a single case of jaundice occurred among the employees of a silk mill using this solvent. Parmenter listed the symptoms as general, nervous, and gastric. The general symptoms are important as a warning of more serious consequences: those affected complained of a sense of fatigue, an inability to concentrate, and a general feeling of discontent. The nervous symptoms are headache, vertigo, nervousness, insomnia, and weird dreams. The gastric symptoms are loss of appetite, constipation, diarrhoea, eructation, abdominal pain, nausea, vomiting, and loss of weight, most of which appear within two months of employment. There was no definite clinical sign of jaundice. In the blood studies of these cases, Minot and Smith (1921) noted the following abnormalities: (a) progressive increase of large mononuclear cells, often reaching $40 \%$, (b) the appearance of many immature large mononuclears, (c) a slight elevation in the white cell count, (d) a slight but progressive anaemia, and (e) some increase in the number of platelets. According to these authors "A high mononuclear count is the earliest sign of a reaction to tetrachloroethane" and a worker should be removed from exposure if he shows the slightest clinical sign.

Five fatal cases due to tetrachloroethane in Japan are of interest. The death of a woman worker in a rubber factory from acute liver disease aroused suspicion that the cause might have been tetrachloroethane (K. Horiuchi, 1960, personal communication). Inquiries by the Labour Inspection Officer revealed that four other women from the same factory had died from the same disease. There were high concentrations of both tetrachloroethane and trichlorethylene in one process of the plant, namely 236 and 1,111 p.p.m. respectively, and an additive or synergistic effect might have occurred. The principal cause of the acute liver damage was thought to be tetrachloroethane.

In Hungary, of the workers exposed to it in a penicillin factory and observed for a period of three years, $66 \%$ complained of digestive disturbances, $29 \%$ of headache and weakness, and $4 \%$ of loss of weight. The liver was enlarged in $38 \%$ of those exhibiting symptoms and the liver function tests were abnormal in most cases (Jeney, Bartha, Kundor, and Szendrei, 1957).

\section{Environmental Appraisal}

Description of Bangle Manufacture.-A bundle of used and roughened cellulose acetate film deprived of its silver nitrate is cut into strips, rolled into a small cylinder, and passed through a $50 \%$ mixture of tetrachloroethane and acetone, and then wound onto a round wooden block. (During the wet months (June to September) a small amount of diacetone alcohol is added to the mixture.) Two workers (Fig. 1) who work facing each other and are usually seated on the floor are engaged in this process. As tetrachloroethane is much heavier than air, workers at floor level are more exposed than those who work standing or sitting on a platform. A good deal of the solvent drops into an open enamelled tray placed between the two workers and below the wooden block on which the film is wound. Both hands of the cylinder maker are wet with the tetrachloroethane/acetone mixture, while only one 


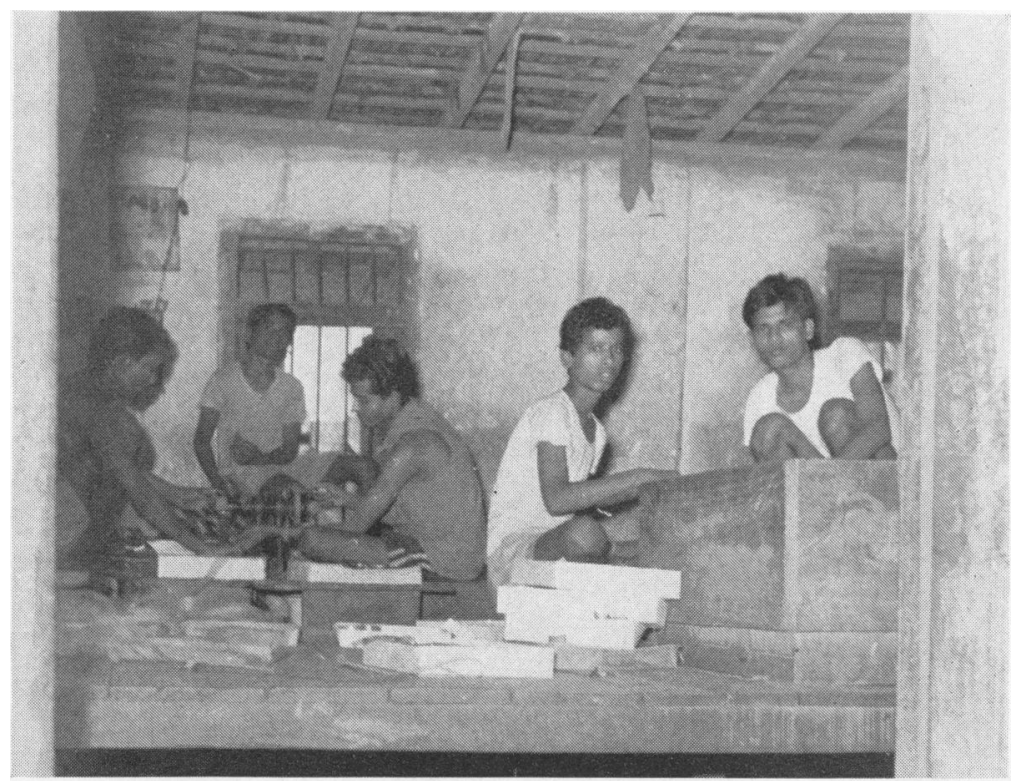

FIG. 1.-Workers engaged in cutting and rolling roughed acetate film and then dipping it into a $50 \%$ mixture of tetrachloroethane and acetone.

hand of the turner is contaminated as he puts pieces of cellulose nitrate film into the cylinder. These small cylinders are heated and then adjusted by passing a round wooden rod through them. This work is usually carried out by women squatting outside the main factory. The cylinder is then cut into six or eight bangles on a revolving machine. At this stage the bangles appear dull. They are, therefore, dipped by hand into a bowl of pure tetrachloroethane and polished, usually by a young

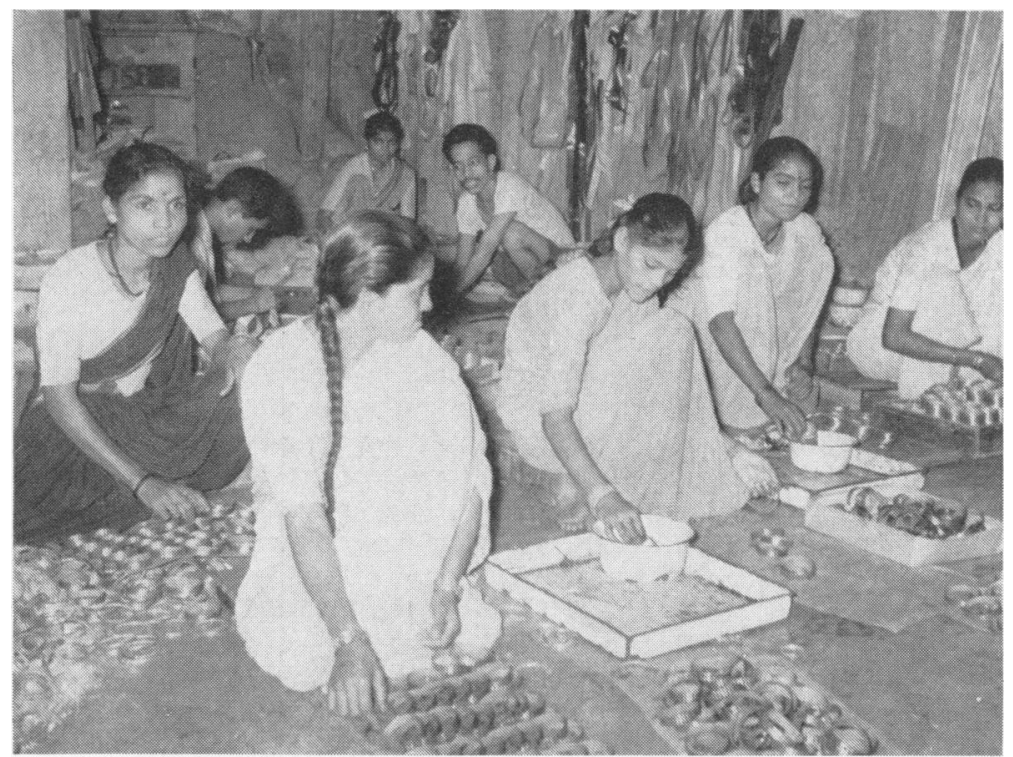

FiG. 2.-Bangles being dipped by hand into a bowl of pure tetrachloroethane and polished. 
TABLE 2

RESULTS OF AIR ANALYSIS

\begin{tabular}{|c|c|c|c|c|}
\hline Date & Factory & Place & $\begin{array}{l}\text { Tetrachloroethane } \\
\text { (p.p.m.) }\end{array}$ & Remarks \\
\hline March 31, 1960 & $\mathbf{A}$ & $\left\{\begin{array}{l}1: \text { Near cylinder making at breath- } \\
\text { ing zone of } 2 \text { workers } \\
2: \text { Near cylinder making at breath- } \\
\text { ing zone of } 2 \text { workers }\end{array}\right.$ & $\begin{array}{l}39 \cdot 3 \\
74 \cdot 1\end{array}$ & $\begin{array}{l}\text { Cylinder making was carried out on platform } \\
\text { between door and windows on which } \\
\text { workers squatted } \\
\text { Work was carried out on platform situated } \\
\text { between } 2 \text { windows; ventilation bad }\end{array}$ \\
\hline August 27, 1960 & G & $\left\{\begin{array}{l}\text { 1: At packing, but near cylinder } \\
\text { making } \\
\text { 2: At cylinder making }\end{array}\right.$ & $\begin{array}{r}9 \cdot 1 \\
17 \cdot 4\end{array}$ & $\begin{array}{l}\text { Quite good cross ventilation; several windows } \\
\text { and doors to room } \\
\text { Quite good cross ventilation; several windows } \\
\text { and doors to room }\end{array}$ \\
\hline August 27, 1960 & $\mathbf{H}$ & $\left\{\begin{array}{l}\text { 1: At heating between workers } \\
\text { 2: Cylinder cutting, } 15 \mathrm{ft} . \text { from } \\
\text { polishing }\end{array}\right.$ & $\begin{array}{r}10 \cdot 59 \\
14 \cdot 00\end{array}$ & $\begin{array}{l}25 \mathrm{ft} \text {. from polishing in small shed with } 3 \\
\text { walls, one side open } \\
\text { Factory like shed with walls on } 2 \text { sides }\end{array}$ \\
\hline July 27,1960 & $\mathbf{L}$ & $\left\{\begin{array}{l}1: \text { At cylinder making } \\
2: \text { At cylinder making }\end{array}\right.$ & $\begin{array}{l}98 \cdot 00 \\
65 \cdot 00\end{array}$ & $\begin{array}{l}\text { On platform in small room with one window } \\
\text { only, no ventilation } \\
\text { In centre of large room away from door }\end{array}$ \\
\hline July 27,1960 & $\mathbf{R}$ & & & \\
\hline May 7, 1960 & $\mathbf{S}$ & $\left\{\begin{array}{l}1: \text { At cylinder making } \\
2: \text { At polishing }\end{array}\right.$ & $\begin{array}{l}60 \cdot 56 \\
40 \cdot 58\end{array}$ & $\begin{array}{l}\text { In corner of room } \\
\text { At breathing zone, workers squatting on } \\
\text { floor near doors }\end{array}$ \\
\hline February 27, 1960 & $\mathbf{J}$ & $\left\{\begin{array}{l}\text { 1: At polishing } \\
\text { 2: Near polishing } \\
\text { 3: Near polishing }\end{array}\right.$ & $\begin{array}{l}61 \cdot 48 \\
50 \cdot 00 \\
20 \cdot 49\end{array}$ & $\begin{array}{l}\text { Polishing done on table, workers standing at } \\
\text { side } \\
\text { At floor level, } 3 \mathrm{ft} \text {. from table } \\
10 \mathrm{ft} \text {. from table, about } 2 \mathrm{ft} \text {. above floor at } \\
\text { breathing zone of workers using amylacetate }\end{array}$ \\
\hline
\end{tabular}

man or a woman (Fig. 2). Due to the action of the solvent the bangles stick together and these are then separated and dried by other workers, so that the hands of the dippers and separators come into contact with pure tetrachloroethane. The bangles are then sorted and packed for the market.

Air Analysis.-Tetrachloroethane was estimated by the Fahy method (1948). The gas was collected in different locations by means of a midget impinger on silica gel contained in a tube, one end of which was drawn out. The gel was then extracted with alcohol, the alcohol treated with potassium hydroxide and the resulting chloride titrated against $0.01 \mathrm{~N}$ silver nitrate. The sampling tube was held in the breathing zone of the worker. As tetrachloroethane is estimated in the form of chloride the other chemicals used should not interfere with the final result. The findings are recorded in Table 2.

In cylinder making, droplets were thrown about by the moving wheel on which the film was wound, and a good deal of the solvent evaporated from the open tray placed below the turning wheel.

Medical Survey.-The examination was undertaken by the medical personnel of the Factory Inspection Office, Government of Maharashtra (formerly Government of Bombay). A survey form adapted from Parmenter (1921) was used. Case histories were taken and each worker was examined. In evaluating exposure it must be emphasized that most workers move from one factory to another because of the prospect of more pay and new workers are moved from one process to another. In view of this, it was recognized that the medical survey had certain limitations. It did not include workers who had become ill and left the employment or those who had left or been discharged for any reason and then subsequently developed symptoms or illness. The labour turnover affected the population studied in terms of duration of exposure and skill of operation. In addition there was no way of determining the long-term effects on the population studied.

Population Studied.-Three hundred and eighty workers were examined in 23 factories employing 474 persons. The number of workers examined in each factory averaged $80 \%$ of the population. Of the women $70 \%$ were under 30 and $82 \%$ were under 26 years of age; the work they perform is mainly unskilled, i.e. polishing, separating, and turning. In the skilled jobs of cylinder making and cutting older men were employed, but there are only a few jobs of this kind. 
Duration of Employment.-The temporary nature of the employment in these factories is indicated by the fact that more than one-third of the workers (both men and women) work for a year or less in a factory. They move from factory to factory or change their occupation for various reasons; some of them go to their native place and, on return, change their place of work for better wages, and it often happens that, when an investigator goes to the factory for a second examination, quite a number of the workers have left.

\section{Clinical and Toxicological Aspects}

Findings.-Of the 380 workers examined, 192 were in direct contact with tetrachloroethane, i.e. 85 in cylinder making, and 107 in polishing and separating. Some of the remaining 188 workers were probably exposed to atmospheric contamination or through occasional change of work. The women workers (80 in number) were employed mostly in the process of adjusting the size of the plastic cylinder before it was cut into individual bangles, and this work was generally carried out outside the main premises of the factory. Even there the MAC of tetrachloroethane was exceeded. In a few cases, however, women were engaged in polishing and separation and thus were liable to inhale as well as to absorb tetrachloroethane through the skin. In some cases they were doing odd jobs such as sticking multicoloured celluloid strips together in the main factory where fumes were always present.
The signs of poisoning in the workers in the various departments are shown in Table 3. Nervous symptoms and signs were the most frequent. In cylinder making and turning, and polishing and separating, workers come in direct contact with tetrachloroethane and, therefore, suffer from the milder symptoms characteristic of tetrachloroethane poisoning with the nervous symptoms predominating. Among the cylinder makers and turners headache and vertigo occur to the extent of 26 and $39 \%$ respectively, and among the polishers 33 and $40 \%$.

To elicit tremors, workers were asked to stand up, close their eyes, and extend their arms fully in front. A fine tremor of the fingers was noticeable, particularly the middle three fingers. Over $63 \%$ of the cylinder makers and $35 \%$ of the polishers had tremors (Table 3); both these groups of workers handle tetrachloroethane to a great extent. However, $40(21: 3 \%)$ who had not handled it at any time exhibited tremors, but they were exposed to the vapour present in the general atmosphere of the factory. No worker except one, who had very pronounced tremor, knew that tetrachloroethane gave rise to this symptom.

In the four departments, cylinder making and turning, heating, cylinder cutting, and polishing, a considerable number of workers were affected by gastric symptoms. Over $22 \%$ complained of loss of appetite and the younger workers among the turners and polishers stated that on those days that they

TABLE 3

NUMBER OF WORKERS SHOWING SIGNS AND SYMPTOMS

\begin{tabular}{|c|c|c|c|c|c|c|c|c|c|c|c|c|c|c|c|c|c|}
\hline \multirow[b]{2}{*}{$\begin{array}{l}\text { Department } \\
\text { (work) }\end{array}$} & \multirow[b]{2}{*}{$\begin{array}{l}\text { है } \\
\text { 京 } \\
\dot{3} \\
\dot{0} \\
\dot{0} \\
\dot{z}\end{array}$} & \multicolumn{5}{|c|}{ General Symptoms } & \multicolumn{6}{|c|}{ Gastric Symptoms } & \multicolumn{5}{|c|}{ Nervous Symptoms } \\
\hline & & 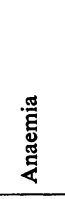 & 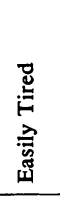 & 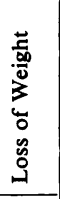 & 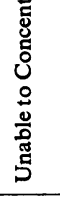 & 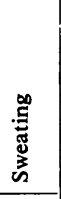 & 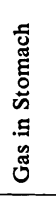 & 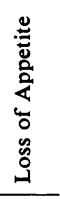 & 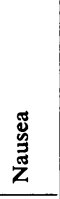 & 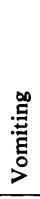 & 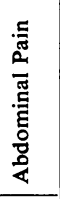 & 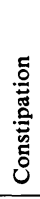 & 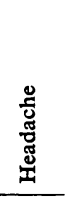 & 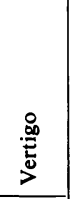 & 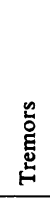 & 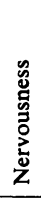 & 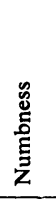 \\
\hline Film grinding & 5 & 2 & 1 & 1 & - & 一 & 1 & - & - & 一 & - & - & 1 & - & 1 & - & - \\
\hline $\begin{array}{l}\text { strip cutting } \\
\text { Sticking sheets }\end{array}$ & $\begin{array}{r}22 \\
5\end{array}$ & $\begin{array}{l}7 \\
3\end{array}$ & 1 & 1 & 二 & $\overline{1}$ & 4 & $\frac{3}{-}$ & $\overline{1}$ & $\underline{2}$ & $\begin{array}{l}4 \\
1\end{array}$ & $\begin{array}{l}1 \\
2\end{array}$ & $\begin{array}{l}3 \\
2\end{array}$ & $\begin{array}{l}3 \\
2\end{array}$ & $\begin{array}{l}6 \\
1\end{array}$ & $\overline{1}$ & 二 \\
\hline $\begin{array}{l}\text { Cylind turning } \\
\text { and turning } \\
\text { Heating } \\
\text { Cylinder cutting }\end{array}$ & $\begin{array}{l}85 \\
50 \\
52\end{array}$ & $\begin{array}{r}33 \\
9 \\
12\end{array}$ & $\begin{array}{r}13 \\
1 \\
4\end{array}$ & $\frac{7}{4}$ & 二 & $\underline{7}$ & $\begin{array}{r}17 \\
1 \\
7\end{array}$ & $\begin{array}{l}22 \\
11 \\
14\end{array}$ & $\begin{array}{r}1 \\
11\end{array}$ & $\begin{array}{l}9 \\
7 \\
2\end{array}$ & $\begin{array}{l}14 \\
16 \\
11\end{array}$ & $\begin{array}{l}5 \\
5 \\
3\end{array}$ & $\begin{array}{r}22 \\
18 \\
8\end{array}$ & $\begin{array}{r}33 \\
22 \\
6\end{array}$ & $\begin{array}{r}54 \\
3 \\
14\end{array}$ & $\begin{array}{r}6 \\
8 \\
-\end{array}$ & $\begin{array}{l}2 \\
2 \\
1\end{array}$ \\
\hline $\begin{array}{l}\text { separating } \\
\text { Packing* } \\
\text { General }\end{array}$ & $\begin{array}{r}107 \\
42 \\
12\end{array}$ & $\begin{array}{r}45 \\
15 \\
2\end{array}$ & $\begin{array}{r}10 \\
2 \\
1\end{array}$ & $\underline{2}$ & $\underline{1}$ & $\frac{13}{-}$ & $\begin{array}{r}11 \\
4 \\
-\end{array}$ & $\begin{array}{r}28 \\
8 \\
-\end{array}$ & $\frac{10}{-}$ & $\begin{array}{r}13 \\
2 \\
-\end{array}$ & $\begin{array}{r}36 \\
6 \\
2\end{array}$ & $\begin{array}{l}7 \\
3 \\
1\end{array}$ & $\begin{array}{l}36 \\
11 \\
-\end{array}$ & $\begin{array}{r}43 \\
7 \\
-\end{array}$ & $\begin{array}{r}39 \\
14 \\
1\end{array}$ & 二 & $\underline{5}$ \\
\hline $\begin{array}{l}\text { Total } \\
\text { Percentage }\end{array}$ & 380 & $\stackrel{128}{33 \cdot 7}$ & $\begin{array}{l}33 \\
8 \cdot 7\end{array}$ & $\begin{array}{l}8 \\
2 \cdot 1\end{array}$ & $\begin{array}{l}1 \\
0 \cdot 2\end{array}$ & $\begin{array}{c}21 \\
5.5\end{array}$ & $\begin{array}{l}45 \\
11.8\end{array}$ & $\begin{array}{l}86 \\
22 \cdot 6\end{array}$ & $\begin{array}{c}24 \\
6 \cdot 3\end{array}$ & $\begin{array}{r}35 \\
9\end{array}$ & $\begin{array}{l}90 \\
23.7\end{array}$ & $\begin{array}{r}27 \\
7\end{array}$ & $\begin{array}{c}101 \\
26.6\end{array}$ & $\begin{array}{c}116 \\
30 \cdot 5\end{array}$ & $\begin{array}{r}133 \\
35\end{array}$ & $\begin{array}{r}29 \\
7\end{array}$ & $\begin{array}{c}10 \\
2.6\end{array}$ \\
\hline
\end{tabular}

Several workers had more than one symptom.

*Workers on these processes are often moved to other work. 
worked with the solvent they felt nausea, had abdominal pain, and vomited. Several of the women also complained of these symptoms. Probably for economic reasons the workers did not seem to pay much attention to the symptoms for they did not stay away from work.

Only one young worker had an enlarged liver. $\mathrm{He}$ was a boy of about 19 years who was very anaemic but had no contact with tetrachloroethane. Jaundice was not detected in any of the workers known to have been exposed under varying working conditions, and one woman with yellow tinged conjunctivae was said never to have been exposed to tetrachloroethane.

A three-month exposure appears to be the critical time at which a combination of symptoms appears and, after six months, a more consistent series of symptoms is evident. The percentage of workers having tremors increases with the amount of tetrachloroethane in the air (Table 4).

Blood Examination.-Although anaemia was observed in 128 out of the 380 examined, one cannot attach much importance to this observation since anaemia is a common finding among persons of the socio-economic group from which these workers are drawn.

In general workers were reluctant to submit to blood examination, and this does not appear to hold out promise as a satisfactory means of keeping a check on health of workers in this cottage industry as they generally live in rural unhygienic surroundings. Many of them are probably infected with worms and this may be the cause of anaemia which is prevalent among them.

The urine of several cylinder makers and turners was tested for urobilinogen with Ehrlich's aldehyde reagent, but the result was negative.

\section{Prevention and Control}

It is recognized that the principles of prevention and control for a toxic substance remain the same whether for a cottage industry or a highly industrialized one; however, socio-economic factors and living standards, as well as the general health of the population, modify what may be possible or desirable in terms of control measures. For all these workers this is their only means of livelihood, and illness of a mild nature is disregarded. It is essential too that small industry survives, and it is to be hoped that as new industry develops in India ventilation and control measures will be installed when the factories are constructed. However, for many reasons the cottage industry will continue and will serve a useful purpose.
TABLE 4

COMPARISON BETWEEN CONCENTRATION AND PERCENTAGE OF WORKERS HAVING TREMORS

\begin{tabular}{c|c|c}
\hline Factory & $\begin{array}{c}\text { Tetra } \\
\text { (p.p.m.) }\end{array}$ & $\begin{array}{c}\text { Percentage of Workers Handling } \\
\text { Tetra and Having Tremors }\end{array}$ \\
\cline { 1 - 2 } G & $9-17$ & 14 \\
A & $40-74$ & 33 \\
L & $50-61$ & 41 \\
\hline
\end{tabular}

Engineering Measures.-The greatest exposure occurs from inhalation and then from absorption through the skin. The fact that the vapour is six times as heavy as air creates certain problems of ventilation control. Mechanization poses many problems because of the nature, rapidity, and number of details in the process as well as the action of the solvents and properties of the materials used. Since the labour supply is virtually unlimited, there will probably be no strong incentive for mechanization. The work should therefore be carried out as far as possible in the open or under open sheds.

Health Education.-Proper health education in the use of protective equipment and to improve the general health of the worker is essential. This is fundamental to the success of all preventive and control measures in use or contemplated for this industry. The workers should be instructed in the best and safest ways of performing their work and protecting themselves from the risk of poisoning. Splashing and spilling of the solvent should be avoided.

Medical Examinations.-Pre-employment examinations are highly desirable so that the health of the workers can be determined and in order to identify those persons who already have symptoms of illnesses similar to those attributed to tetrachloroethane. Persons suffering from anaemia, gastritis, nervous diseases, and those suffering from, or prone to, liver disease should not be engaged.

The prevailing concentration of tetrachloroethane in the work atmosphere and the extent of the circumstances which cannot be controlled determine the frequency of the medical examinations. In this cottage industry the workers should be examined at least every three months.

Similarly, although the examination of the blood is important, we do not think that the routine examination of blood is practical for this cottage industry. Ehrlich's urobilinogen test is recommended as a routine in these factories. Further liver function tests would be highly desirable. The diet 
of these workers consists mainly of rice and occasionally of wheat chapaties (hand-made bread); meat is eaten only once or twice a month. Under these circumstances any exposure beyond eight hours a day in the work area should be avoided. Workers with tremors should be examined at monthly intervals and if they grow worse or show signs of liver involvement they should be removed from exposure. At the same time the environment should receive urgent attention.

Jaundice due to the solvent has not been seen so far, but, should it occur, the worker should be immediately given leave of absence of about three weeks and should be allowed to resume work only when the jaundice has completely disappeared. When he returns, he should be placed in areas where he is not exposed or where exposure is minimal. If he is to resume his original work, this should be done gradually and a careful watch should be kept on his jaundice and liver. If the worker has severe symptoms, deep jaundice, repeated vomiting, or an enlarged liver, he would be very prone to a recurrence with serious consequences. When such a case occurs he should be banned from any exposure to tetrachloroethane. Although there has been some speculation about workers becoming resistant to the effects of tetrachloroethane, we could not determine this because of the rapid labour turnover, frequent changes in work assignments, and job areas.

My thanks are due to Shri N. L. Gadkari, Chief
Inspector of Factories, Maharashtra State, for the encouragement received during the survey.

The clinical examination was carried out with the help of Dr. Mrs. R. Madon, Lady Inspector of Factories, and Dr. R. C. Bapat, Certifying Surgeon. Some of the workers were later re-examined by Dr. G. G. Davay, Junior Medical Inspector of Factories.

Air analysis was undertaken by Shri S. C. Kale and the blood examination by Kumari S. J. Vesuna at the Industrial Hygiene Laboratory attached to the Factory Inspection Office; they also compiled the Tables.

I have to thank the above doctors and the staff of the Laboratory for their valuable help.

\section{REFERENCES}

Barlow, F. (1916). Med. Press, 152, 471.

Chief Inspector of Factories (1959). Ann. Rep. on Industrial Health for $1958, \mathrm{p} .22$. H.M.S.O., London.

Elkins, H. B. (1950). The Chemistry of Industrial Toxicology, p. 138. Wiley, New York.

Elliott, J. M.' (1933). J. roy. Army med. Cps, 60, 373.

Fahy, J. P. (1948). J. industr. Hyg., 30, 205.

Forbes, G. (1943). Brit. med. J., 1, 348.

Hamilton, A. (1917). J. Amer. med. Ass., 69, 2037.

Hepple, R. A. (1927). J. roy. Army med. Cps, 49, 442.

Horiuchi, K. (1960). Personal communication. Original work by Horiuchi H. Horiguchi S. et al. Osaka City University, Osaka, Japan.

Jeney, E., Bartha, F., Kundor, L., and Szendrei, S. (1957). Egészségtudomany, 1, 155.

Jungfer (1914). Z Zbl. Gewerbehyg., 2, 222.

Lee, W. E. (1916). Lancet, 1, 24.

Lehmann, K. B. (1911). Arch. Hyg. (Berl.), 74, 1

Minot, G. R., and Smith, L. W. (1921). Arch. intern. Med., 28, 687. Parmenter, D. C. (1921). J. industr. Hyg., 2, 456.

(1923), ibid., 5, 159.

Smith, W. S. (1918a). Ann. Rep. Chief Inspector of Factories for 1917 p. 18. H.M.S.O., London. (1918b) Chem Trade J 63 . 44

Willcox, W. H. (1914). Lancet, 2, 1489. (1915). ibid., 1, 544. Brit. med. J., 1, 300. 